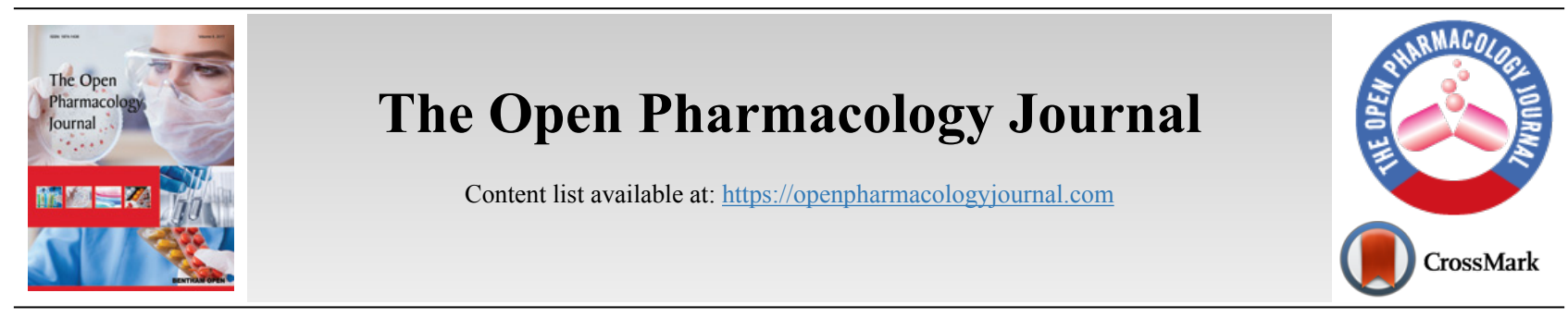

RESEARCH ARTICLE

\title{
Evaluation of Acute Toxicity of the Methanolic Extract of Dhatryadi Ghrita in Wistar Rats
}

\author{
Rashmi Saxena Pal ${ }^{*}$ and Amrita Mishra
}

Department of Pharmacy, NH-2, Bhauti, Pranveer Singh Institute of Technology, Kanpur, India

\begin{abstract}
:
Background:

Dhatryadi ghrita consists of dhatri, is known to have number of curative properties since ages. It does not causes any toxic or adverse effect, but there is no scientific evidence available.

Objective:

The present piece of research is aimed to study the toxic effects in order to lay down the safety parameters of methanolic extract obtained from Dhatryadi Ghrita in wistar rats $(180-200 \mathrm{~g})$ as per the standards set by The Organization for Economic Cooperation and Development or OECD.

\section{Materials and Methods:}

Group 1 was used as a control for comparing the behavior of rats from all groups which were administered extracts of different concentrations. The animals in Group 2 were administered a dose of 1000, Group 3, 2000, and Group 4, 3000, respectively in the units of mg/kg and Group 5 were given a dose of $4000 \mathrm{mg} / \mathrm{kg}$ accordingly.

Results:

The acute toxicity studies of the experiment dealing with different doses as varying from $1000-4000 \mathrm{mg} / \mathrm{kg}$, which did not resulted in any death of any animal till 14 days of observation in the experimentation period.

Conclusion:

Dhatryadi Ghrita is safe in rodent and mice. Hence, the extract is safer for therapeutic use in pharmaceutical formulations. Ghrita in different concentrations were found to be completely safe and non-toxic under acute toxicity studies.
\end{abstract}

Keywords: Acute, Toxicity, Ghrita, Dhatryadi, Curative properties , Methanolic extract.

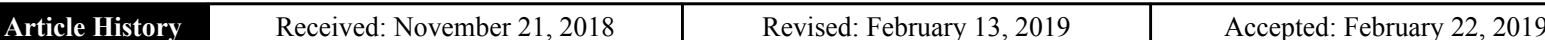

\section{INTRODUCTION}

The concern for seasoning toxicity has emerged as a giant matter of concern for several national and international bodies to formulate and implement numerous tips for assessing, observance and preventing toxicity arising because of seasoning merchandise. For instance, at United Nations agency, metropolis observance Centre takes care of compilation and dissemination of data relating to seasoning drug adverse reactions, whereas Organization for Economic

* Address correspondence to this author at the Department of Pharmacy, NH-2, Bhauti, Pranveer Singh Institute of Technology, Kanpur, India; Tel: +9129826459; E-mail: rashmisaxenapal@gmail.com
Cooperation and Development (OECD) sets tips relating to toxicity study. Several marketed seasoning merchandise area unit are often known to have toxic effects. One analysis study rumored severe hepatotoxicity by using seasoning plants [1]. In step with OECD tips, so as to work and make up one's perception regarding the parameters of safety and efficacy of a replacement drug, pharmacology studies area unit terribly essential in numerous animals like monkey, dog, rabbit, mice etc. pharmacology research functions a criteria to determine whether or not a replacement drug should be used for clinical applications. As per the OECD instructions naming 401, 423 and 425 , that did not enable the clinical use of drug, nor its clinical test additionally as toxicity studies [2,3]. So the correct screening of seasoning merchandise for numerous toxic effects 
before they become expandable is extremely essential.

Table 1. Contents used in Dhatryadi Ghrita.

\begin{tabular}{|c|c|c|c|c|}
\hline S.No & Ingredient & Botanical name & Part used & $\begin{array}{c}\text { Amount } \\
\text { used }\end{array}$ \\
\hline 1. & Amalki & Emblica officinalis & Fresh fruits & $768 \mathrm{ml}$ \\
\hline 2. & Vidari & Pueraria tuberosa & $\begin{array}{c}\text { Tuberous } \\
\text { roots }\end{array}$ & $768 \mathrm{ml}$ \\
\hline 3. & Iksu & $\begin{array}{l}\text { Saccharum } \\
\text { officinarum }\end{array}$ & Dried stem & $768 \mathrm{ml}$ \\
\hline 4. & Shatavari & $\begin{array}{l}\text { Asparagus } \\
\text { racemosus }\end{array}$ & $\begin{array}{c}\text { Tuberous } \\
\text { roots }\end{array}$ & $768 \mathrm{ml}$ \\
\hline 5. & Kusmanda & Benincasa hispida & Dried fruits & $768 \mathrm{ml}$ \\
\hline 6. & Draksha & Vitis vinifera & Dried fruits & $24 \mathrm{gms}$ \\
\hline 7. & Yasti & Glycyrrhiza glabra & $\begin{array}{c}\text { Stolon and } \\
\text { root }\end{array}$ & $24 \mathrm{gms}$ \\
\hline 8. & $\begin{array}{c}\text { Shwet } \\
\text { Chandan }\end{array}$ & Santalum album & Heart wood & $24 \mathrm{gms}$ \\
\hline 9. & Go ghrita & $\begin{array}{c}\text { Butyrum } \\
\text { deparatum }\end{array}$ & - & $768 \mathrm{ml}$ \\
\hline 10. & Go Dugdha & Ksira & - & $768 \mathrm{ml}$ \\
\hline 11. & Sugar & Khanda & - & $24 \mathrm{gms}$ \\
\hline
\end{tabular}

Toxicity, safety, and efficaciousness parameters area unit to be determined for any polyherbal combination in appropriate animal models as per the protocols of regulative norms will aid in predicting toxicity and serving tips for choosing a secure dose in humans. Dhatryadi Ghrita is an Ayurvedic medication, additionally called seasoning or medicated drawn butter as its base and it is prescribed for the treatment of assorted central nervous system disorders. Its main ingredient is Dhatri (Emblica officinalis) [4]. Table 1 summarizes all the ingredients with their botanical name and amounts utilized in Go-Ghrita [5]. Dhatryadi Ghrita has Madhura rasa, Sita Veerya and Madhura Vipaka [6 - 9]. The advancement of analytical techniques is uniquely acting as an effective tool within the space of seasoning drug analysis, thereby, facilitating the makers to line up quality standards and parameters, so as to confirm promoting approval from regulative authorities for therapeutic efficaciousness, safety and shelf- lifetime of medicine [10]. Depending on the tenure of drug administration imparted to animals, pharmacological medicine estimation is especially of 3 types like acute, sub-acute and chronic pharmacological studies. The acute toxicity measure is that one dose is employed in every animal on one occasion so as to estimate the gross behavior and additionally LD50 or median dose [11]. so as to judge the toxic nature of pharmaceutically bioactive compound gift within the plant extract or its formulation, acute oral toxicity is that the initiative to be performed. Acute toxicity measurement deals with that dose that kills five hundred of the tested group of animals [12].

\section{MATERIALS AND METHODS}

\subsection{Experimental Design}

Acute oral toxicity was dispensed to see the LD50 worth of methanolic extract of Dhatryadi Ghrita. Experiments were dispensed on Wistar rats, varying within the weight from 175-200 g. The Institutional Ethical Committee of Pharmacy department, 1273/PO/Re/S/09/CPCSEA for analysis for education purpose on little animals, PSIT, Kanpur, India approved the protocol for these experiments underneath range [13].

\subsection{Housing and Nutrition}

The animals were kept in cages with wood litter and also the temperature was maintained optimum. Lighting was ensured to produce twelve hours of sunshine and twelve hours of dark, alternately for every twenty-four hours amount. Every cage was assigned a separate card, revealing a number of the particular cage and weight of the animals present in it, details of the administered drug, route of administration and level of dose. The animals were given animal food, along with water as needed.

\subsection{Acute Oral Toxicity Test}

The Wistar rats were sorted into 5 teams that contained six male Wistar rats. The animals were recognized by marking them with acid staining technique for identification. Then animals in cluster one were thought of as management cluster animals that weren't administered any drug extract. Cluster one was used as management for examining the behavior of rats from all teams that were administered extracts of various concentrations. The animals in cluster pair were administered a dose of a thousand $\mathrm{mg} / \mathrm{kg}$, cluster three were administered $2000 \mathrm{mg} / \mathrm{kg}$ dose, cluster four were administered a dose of three thousand $\mathrm{mg} / \mathrm{kg}$ severally, and cluster five were administered a dose of $4000 \mathrm{mg} / \mathrm{kg}$.

\subsection{Mode of Administration and Symptoms Recorded Throughout the Study}

Acute oral toxicity studies were performed strictly as per the directions of OECD parameters. Wistar strain rats were chosen randomly by sampling technique in order to perform the experiment. The animals were devoid of food for twelve hours with free reach only to water. After this, the animals were weighed and administrated the oral extract, ranging at a dose of 1000 to $4000 \mathrm{mg} / \mathrm{kg}$. After the extract administration, the animals were looked after for two hours. The mortality and lab findings including variation in color of skin, membrane, pupil of eyes were recorded within primary first four hours, later on for seventy-two hours and henceforth for seven days of drug extract administration. For the entire seven days, the main observations like body postures, movements, rearing, tremors, absorbance were observed and additionally the result of dose on pain, touch response, righting reflex etc were recorded. Additionally, the input of dietary behavior was additionally notified.

Table 2. Dosing and observation period.

\begin{tabular}{|c|c|c|c|}
\hline S. No. & Group & Dosing & Observation Period \\
\hline 1. & Group 1 & Saline & 4 hours, 72 hours, 7 days \\
\hline 2. & Group 2 & Drug extract $1000 \mathrm{mg} / \mathrm{kg}$ & 4 hours, 72 hours, 7 days \\
\hline 3. & Group 3 & Drug extract $2000 \mathrm{mg} / \mathrm{kg}$ & 4 hours, 72 hours, 7 days \\
\hline 4. & Group 4 & Drug extract $3000 \mathrm{mg} / \mathrm{kg}$ & 4 hours, 72 hours, 7 days \\
\hline 5. & Group 5 & Drug extract $4000 \mathrm{mg} / \mathrm{kg}$ & 4 hours, 72 hours, 7 days \\
\hline
\end{tabular}




\subsection{Dosing}

The toxicity studies were performed as per the OECD tips. The Wistar rats $(n=6)$ were indiscriminately designated and used for the study. The animals were devoid of food until twelve hours with complete reach to water. Within the period of abstinence the animals were weighed and severally the four concentrations of extract for e.g. one thousand, 2000, 3000 and $4000 \mathrm{mg} / \mathrm{kg}$ were administered to every cluster orally as mentioned in the Table 2 . After administration of extracts, the animals were kept away from food till two hours. Shortly, the food was made available.

\subsection{Acute Toxicity Studies}

The acute toxicity studies were administered for 6 Wistar rats wherever individual doses in $1000 \mathrm{mg} / \mathrm{kg}$ ranging to 4000 $\mathrm{mg} / \mathrm{kg}$ were administered by oral feeding. The final behavior and mortality were determined and recorded for forty-eight hours from the time of dosing until seven days. The animals that survived were determined for behavioral activities and different symptoms like locomotion etc. The clinical symptoms were conjointly recorded within the study of parameters like color changes, fur density, eyes etc. for the initial four hours when dosing and after until seventy of two hours from the dosing time. The observation and recording of the activities were administered for seven days from drug administration. The whole behavior of the animal was studied with the assistance of body posture, tremors, locomotion, gait, rearing, grip strength, lightning reflex, pain response, food intake, driblet, water intake and general body positions. These symptoms were noted for fourteen days. All the four clusters exhibited more or less normal and routine responses.

\subsection{Observation}

The effect of the extracts on acute oral toxicity studies in all clusters of animals were observed and recorded are as follows as in Table 3 .

Table 3. Effects of the extracts on acute oral toxicity.

\begin{tabular}{|c|c|c|c|c|c|c|}
\hline $\begin{array}{c}\text { S. } \\
\text { No. }\end{array}$ & Response & $\begin{array}{c}\text { Control } \\
\text { Group }\end{array}$ & $\begin{array}{c}\text { Cluster } \\
\mathbf{1}\end{array}$ & $\begin{array}{c}\text { Cluster } \\
\mathbf{2}\end{array}$ & $\begin{array}{c}\text { Cluster } \\
\mathbf{3}\end{array}$ & $\begin{array}{c}\text { Cluster } \\
\mathbf{4}\end{array}$ \\
\hline 1. & Alertness & Usual & Usual & Usual & Usual & Usual \\
\hline 2. & Restlessness & -ve & -ve & -ve & -ve & -ve \\
\hline 3. & Grooming & -ve & -ve & -ve & -ve & -ve \\
\hline 4. & Touch response & Usual & Usual & Usual & Usual & Usual \\
\hline 5. & Pain response & Usual & Usual & Usual & Usual & Usual \\
\hline 6. & Tremors & -ve & -ve & -ve & -ve & -ve \\
\hline 7. & Righting reflux & Usual & Usual & Usual & Usual & Usual \\
\hline 8. & Salivation & Usual & Usual & Usual & Usual & Usual \\
\hline 9. & Pupils & Usual & Usual & Usual & Usual & Usual \\
\hline 10. & Urination & Usual & Usual & Usual & Usual & Usual \\
\hline 11. & Food intake & Usual & Usual & Usual & Usual & Usual \\
\hline 12. & Water intake & Usual & Usual & Usual & Usual & Usual \\
\hline 13. & Convulsion & -ve & -ve & -ve & -ve & -ve \\
\hline 14. & Writhing & -ve & -ve & -ve & -ve & -ve \\
\hline 15. & Gripping & Usual & Usual & Usual & Usual & Usual \\
\hline 16. & Skin color & Usual & Usual & Usual & Usual & Usual \\
\hline
\end{tabular}

\begin{tabular}{|c|c|c|c|c|c|c|}
\hline 17. & $\begin{array}{c}\text { Fur } \\
\text { shedding/density }\end{array}$ & Usual & Usual & Usual & Usual & Usual \\
\hline 18. & Corneal reflex & -ve & -ve & -ve & -ve & -ve \\
\hline 19. & Torch response & Usual & Usual & Usual & Usual & Usual \\
\hline 20. & Mortality & $\begin{array}{c}\text { Not } \\
\text { applicable }\end{array}$ & -ve & -ve & -ve & -ve \\
\hline
\end{tabular}

\section{RESULTS}

The acute toxicity studies performed with the doses ranging from 1000 to $4000 \mathrm{mg} / \mathrm{kg}$ did not resulted in death of any animal until fourteen days of observation within the experimentation tenure. The animals from any cluster did not reveal any signs of acute toxicity or any major effect on normal behavior. The signs like changes in locomotion, lachrymation, piloerection, respiration etc. were found to be chiefly traditional in teams so stating associate degree illation that the drug concentrations were found to be utterly safer to be used and non-toxic beneath acute toxicity studies . Acute toxicity determination serves as a unique technique utilized in assessing acute oral toxicity that involves the determination of a dose level that results in death. The dose limits were elite on the idea of oral acute toxicity studies in rats in line with OECD tips. Parameters like activeness, grooming, laziness, bite, touch and pain reaction, shakings, convulsion, gripping, pinna reflex, writhing pupils, urine and saliva production, color of skin, lachrymation, food and water input and death were discovered (Table 3). All teams of animals displayed neither any virulent result nor any deadly result. This study revealed that administration of dose up to $4000 \mathrm{mg} / \mathrm{kg}$, did not reveal any symptoms of toxicity or death in rats throughout the complete experimentation tenure. Hence, LD50 of extract could also be thought of to be larger than $4000 \mathrm{mg} / \mathrm{kg}$. Ghrita did not induce any abnormal behavior. No mortality was observed during 14 days after treatment with ghrita.

\section{DISCUSSION}

Pharmacological extracts and formulation tests are essential to be performed to observe the security and effectualness of merchandise like individual compounds, mixture of compounds, crude extracts, reaction intermediates, pesticides, finished products, pharmaceutical excipients and aids, medicines, cosmeceuticals and other chemical ingredients. It has been recommended that healthful herbs would be in the most ample supply to spread them on larger scales to fulfill the increasing demands. Hence, such beneficial herbs should be evaluated for higher applications of their healthful benefits, safety and efficacy [14, 15]. Safety of polyherbal extract is evaluated principally by estimation of acute oral toxicity. Within the study, even the highest dose of plant extract i.e. $4000 \mathrm{mg} / \mathrm{kg}$ did not show any symptoms of toxication and death in for animals. Therefore, this polyherbal extract even at $4000 \mathrm{mg} / \mathrm{kg}$ could also be recommended as safe and offers no harm to the animals. It indicates that ghrita has more short chain fatty acid and unsaturated fats, which might be due to pharmaceutical processing of ghrita. Short Chain Fatty Acids (SCFAs) are readily absorbed; a greater increase in SCFAs production and potentially a greater delivery of SCFAs. Unsaturated fat supplementation increases total dietary energy intake to recommended levels, has no adverse impact on blood 
lipids. It also improves nutritional status and possesses health benefits. Ghrita beyond treating serious mental disorders can be used to pacify anxiety [16 - 20].

\section{CONCLUSION}

The safe and efficacious nature of methanolic extract prepared from the Ayurvedic polyherbal ghrita was confirmed and established by acute oral toxicity check conducted as per the regulations of OECD. The uniform and stable behavior and response of animals throughout the experimentation of two weeks offered the safe and harmless behavior of methanolic extract in animals upto dose of even up to $4000 \mathrm{mg} / \mathrm{kg}$. Any studies further are guaranteed together with sub acute and chronic pharmacological evaluations to ensure the fruitful use of this extract for numerous medical specialty functions and other pharmacological applications. Dhatryadi ghrita have a broad safety margin in experimental animals might be due to interaction of ingredients.

\section{ETHICS APPROVAL AND CONSENT TO PARTI- CIPATE}

All the reported experiments in the study were approved by the Institutional Ethical Committee of Pharmacy department, 273/PO/Re/S/09/CPCSEA for analysis of education purpose on little animals, Pranveer Singh Institute Of Technology, Kanpur, India.

\section{HUMAN AND ANIMAL RIGHTS}

No humans were used in the study. All the reported experiments on animals were in accordance with the OECD guidelines (March 2008) which were laid down in the early 1980s (then repeatedly updated) to regulate the toxicity testing of pharmaceutical substances on animals.

\section{CONSENT FOR PUBLICATION}

Not applicable.

\section{CONFLICT OF INTEREST}

The authors declare no conflict of interest, financial or otherwise.

\section{ACKNOWLEDGEMENTS}

Declared none.

\section{REFERENCES}

[1] Schoepfer AM, Engel A, Fattinger K, et al. Herbal does not mean innocuous: Ten cases of severe hepatotoxicity associated with dietary supplements from Herbalife products. J Hepatol 2007; 47(4): 521-6. [http://dx.doi.org/10.1016/j.jhep.2007.06.014] [PMID: 17692989]

[2] Ecobichon Ansari SH. Essential of pharmacognosy. $1^{\text {st }}$ ed. New Delhi: Birla Publications Pvt. Ltd. 2007.

[3] Kofi Donkor A, Laud NK. Okine, Wonder K. M. Abotsi, Eric Woode. Acute and sub-chronic toxicity studies of aqueous extract of root bark of cassia sieberiana D.C. in rodents. J Appl Pharm Sci 2014; 4(4): 84-9.

[4] Pal RS, Mishra A. A review on Dhatryadi ghrita. Int J Res Ayurveda Pharm 2017; 8(Suppl. 2): 190-5.

[http://dx.doi.org/10.7897/2277-4343.082111]

[5] The Ayurvedic Formulary of India. Government of India. 2003.

[6] The Ayurvedic Pharmacopoeia of India. Government of India, Ministry of Health and family welfare, Department of AYUSH. 2001; I: 4-5. 62, 127-8.

[7] The Ayurvedic Pharmacopoeia of India, Government of India, Ministry of Health and family welfare, Department of AYUSH. 2001; II: 48-9. 173-4.

[8] The Ayurvedic Pharmacopoeia of India, Government of India, Ministry of Health and family welfare. Department of AYUSH 2001; III: 45-6.

[9] The Ayurvedic Pharmacopoeia of India, Government of India, Ministry of Health and family welfare, Department of AYUSH. 2001; IV: 55-6. 108-9.

[10] Pal RS, Mishra A. Standardization of dhatryadi ghrita: A herbal ghee based ayurvedic medicinal preparation. Open Med J 2018; 5: 47-55. [http://dx.doi.org/10.2174/1874220301805010047]

[11] Bhardwaj S, Gupta D. Study of acute, subacute and chronic toxicity test. Int J Adv Pharm Biol Sci 2012; 2: 103-29.

[12] Akhila JS, Deepa S, Alwar MC. Acute toxicity studies and determination of median lethal dose. Curr Sci 2007; 93: 917-20.

[13] Nascimento Antman EM, Braunwald E. ST-elevation myocardial infarction: pathology, pathophysiology, and clinical features.Braunwald's heart disease: A textbook of cardiovascular medicine. Philadelphia, PA: Saunders Elsevier 2008; pp. 1207-32.

[14] Pooja S, Prashanth S, Suchetha K, Vidya V, Krishna B. Evaluation of acute and sub acute toxicity of the leaf extract of Tanacetum parthenium (Asteraceae) and synthetic parthenolide. World J Pharm Pharm Sci 2016; 5(8): 703-13.

[15] Olson H, Betton G, Robinson D, et al. Concordance of the toxicity of pharmaceuticals in humans and in animals. Regul Toxicol Pharmacol 2000; 32(1): 56-67.

[http://dx.doi.org/10.1006/rtph.2000.1399] [PMID: 11029269]

[16] Teo S, Stirling D, Thomas S, Hoberman A, Kiorpes A, Khetani V. A 90-day oral gavage toxicity study of D-methylphenidate and D,Lmethylphenidate in Sprague-Dawley rats. Toxicology 2002; 179(3): 183-96.

[http://dx.doi.org/10.1016/S0300-483X(02)00338-4] [PMID: 12270 592]

[17] Hayes AW, Ed. Principles and Methods of Toxicology. $5^{\text {th }}$ ed. New York, NY: Informa Healthcare 2007.

[18] Raza M, Al-Shabanah OA, El-Hadiyah TM, Al-Majed AA. Effect of prolonged vigabatrin treatment on hematological and biochemical parameters in plasma, liver and kidney of swiss albino mice. Sci Pharm 2002; 70: 135-46.

[19] Stephensen CB. Vitamin A, infection, and immune function. Annu Rev Nutr 2001; 21: 167-92.

[http://dx.doi.org/10.1146/annurev.nutr.21.1.167] [PMID: 11375434]

[20] Wintergerst ES, Maggini S, Hornig DH. Immune-enhancing role of vitamin $\mathrm{C}$ and zinc and effect on clinical conditions. Ann Nutr Metab 2006; 50(2): 85-94.

[http://dx.doi.org/10.1159/000090495] [PMID: 16373990] 